\title{
CONSUMPTION AND DEMAND FOR GOODS Maria VĂDUVA
}

\author{
“Constantin Brâncuşì” University Târgu Jiu, Târgu Jiu, Romania \\ vaduva.maria9@gmail.com
}

\begin{abstract}
The free development of the economic activity imposes to establish a relation of subordination of the means by the purposes. The consumption appears both as triggering and simulating element of production, and as control element of this, being the one generating the quantitative and qualitative determinations, and also the sense and intensity of the rhythms where they develop and cyclically resume. The consumption, which is the level where people reach their material purposes generated by the economic interests, must be the fundamental element in conceiving and developing the economic activity.

The link between consumption and market is made through the demand for goods containing a large and complex bid of actions from the consumption field that is going to be performed in the market, making of this a barometer of economic and social development.

When following the internal evolution of consumption, it presents a high degree of interest to surprise the consumption habits and to project its future structures in order to define the evolutionary coordinates of the commercial activity, being the motor force of the production, signifying wear and destruction, involving the change of goods and services consumed with new created goods and services.
\end{abstract}

Keywords: consumption, the gross domestic product, goods, services, income

\section{Introduction}

The bond that links consumption and ensure market through commodity demand.

The consumption is the frame which includes meeting the needs of the society, being the force of production, signifying wearing and the distribution involves changing the consumed goods or services with newly created goods or services.

The connection between consumption and market is made through the demand of goods containing a large and complex sphere of options in the consumption field which is to be performed on the market. Consumption, as an expression of using certain goods and services resulted from the production to meet the people's needs and the production, dresses different forms depending on the nature of met needs, concrete ways to meet the needs, solvency sources of the consumption needs and consumption feeding sources.

Following the domestic development of consumption presents a high degree of interest both for researchers and for practitioners to observe the consumption habits and to project the future structures for defining the progressive coordinates of the commercial activities.

\section{The relation between time evolution of consumption and the gross domestic product}

The relation between time evolution of consumption and the gross domestic product flow presents a special interest. 
In GDP, the total consumption expenditures are the most important category, reaching to hold two-thirds of total GDP; the consumption is the most stable of all the expenditure flows, but it may present fluctuations in terms of its relative aspect. The fluctuations do not reflect the volumetric evolution of proper consumption, but the accentuated quantitative and relative changes of other sectors, those regarding the investments and public expenses.

The mechanism to permanently create new needs and new desires is the main witness of social development.

Taking into account the existing connections between consumption and GDP, we may outline two categories: consumption propensity and Engel's laws.

The consumption propensity is the ratio between the total consumption and the income as GDP elements, offering operational models used in future individual consumption forecasting starting from the evolution of determinant indicators in the macroeconomic level by development programs.

The existence of average and marginal propensities of consumption and of different ways to surprise both the consumption and income makes possible the construction of different types of models regarding consumption propensity.

Consumption has its source in income. The size of income expenditure depend both on the size of the available income and the proportion in which the available income is used for consumption or is saved.

The size of personal consumption expenditure depends on the volume of the income and other objective circumstances to which are added the objective needs. We distinguish between the objective factors: level and dynamic of income - the consumption decision is taken in relation to the size and evolution of the personal net income, unanticipated changes affecting the price of different elements of fixed capital and circulating capital and which are caused by the moral wear and the emphasis of the restrictions to certain natural resources, change of the expectations regarding the ratio between consumption expenditure resulting from the changes in the purchasing power of money or certain risks. This factor is identified with the evolution of interest rate, tax policy change through the accent put on the own budgetary resources or on loans. When the tax policy is used for a better distribution of income, it may accentuate the inclination towards consumption or determine its decrease, if an important part of the budgetary funds are used to pay the public debt.

The subjective factors influencing the inclination towards consumption comprise the psychological inclinations, individuals' habits, providing independence, business spirit, pride and avarice having the effect of reducing consumption expenditure.

Based on objective and subjective factors, Keynes argues that a high proportion of income is saved when the income rises above the level necessary to satisfy the basic needs of the individual and his family. If this is diminished to a very low level, consumption can be reduced to less than this and become higher than the income if it is financed from the previously reserves.

The usual behavior, set up on a high level of previous reached consumption, prevents its decrease with the income. The consumption expenditure depends not only on the actual income, but also on the higher level of income had in the previous period. When the income is reduced, the consumption is subject to the pressure of tow tendencies: the previous level of income retains the level reached in the previous period, and the current level of income tends to minimize it. The combined effect of these two opposed forces causes a decrease in consumption less than proportional to that of the income. An absolute high level of the income tends to increase the difference between income and 
consumption because meeting the basic needs is a strong impulse than an incitement to save, but which begins to assert itself when individuals reach a certain level of wealth.

\section{The relationship between income and consumption}

The relationship between income and consumption is under the fundamental psychological law according to which when the income increases or decreases, people incline to increase or decrease the consumption, but in a lower proportion.

When increasing the income, an increase of consumption takes place. When the income is reduced, usually the consumption is also decreased, but due to the individuals' behavior the income is reduced with a lower measure, at least on short term, thus the consumption outruns the income not only in the household level, but also in the economy.

The research in time of expenditure budgets in different categories of households led to the conclusion that in the context of the overall disorder appearance characterizing the consumption and of apparently anarchic spreads, we can talk about outlining certain restructuring trends in consumption.

The consumption of a typical family is not necessarily constant during the whole period of life. These differences cancel each other in aggregate form, thus the consumption aggregated on long term tends to be proportional with the income on long term.

In the life cycle theory, the individuals' consumption behavior is thought for the whole life period. If the consumption is relatively constant during life, and the earnings is constant along the years of work, a certain percentage of income should be annually saved to ensure maintaining the consumption level of a person during the period when it is no longer employed.

Concerning the distribution of consumption during the entire life, it is assumed that the individual does not want it to show too many oscillations.

This hypothesis relates the consumption to the total income.

The theory of life income and the theory of permanent income do not exclude each other. The first gives greater attention to the motives determining the saving and offers arguments for the inclusion of wealth in the consumption position, and the second emphasizes on the way in which individuals form their expectations on future income.

\section{Conclusions}

If the consumers' expectations are rational, then their estimations regarding the permanent income should be in accordance with the way in which income changes.

Progressive adjustment of consumption to income manifests as a gradual adaptation of income from economy to the changes of autonomous expenditure and to other changes. The increase of autonomous expenses enhances the income during a period due to the fact that income supplement gradually influences the consumption level.

Meeting and final confrontation of the dimensions and structures of consumption with the similar coordinates of production take place in the market under the demandoffer ratio. The demand for goods is one of the phenomena of exchange economy, representing all the relationships built up in connection to the form under which the real need of material goods and services manifests.

The demand for goods as a market category is the materialization form of a real need.

The meeting and the final confrontation of dimensions and consumption structure with the similar coordinates of production takes place in the market under the form of the demand-bid report, and the bid together with the demand make the unitary act of the exchange of goods.

The creation of a perspective strategy to satisfy the consumer needs implies a good knowledge of the demand both in terms of manifestation forms of this, and under its quantitative and structural aspects; the 
demand for goods appears as an expression of consumption.

The development of society, increasing civilization of the population, living needs, both material and spiritual, determined that satisfy consumer need to be completes by using the services.

\section{References}

[1] Marin Dumitru, Marinescu Daniela Elena, Microeconomie avansată. Aspecte teoretice şi aplicaţii, Bucureşti, Editura ASE, 2013.

[2] Socol Cristian, Angelescu Coralia, Socol Aura Gabriela, Politici economice, Bucureşti, Editura Economică, 2009.

[3] Stancu Stelian, Microeconomie. Comportamentul agenţilor economici în condiţii de certitudine, incertitudine şi risc. Teorie şi aplicaţii., Bucureşti, Editura ASE, 2012.

[4] Tănase Diana, Factorii determinanţi ai competitivităţii economice, Bucureşti, Editura Economică, 2013. 